\title{
Hal Koch, Grundtvig and the rescue of the Danish Jews: A case study in the democratic mobilisation for non-violent resistance
}

\author{
By Steven Borish
}

The Danish people's successful cultural mobilisation for resistance against the Nazi Occupation (1940-1945) culminated in the rescue operation that took place in the autumn of 1943 when 7220 of the approximately 7800 Jews then in Denmark were successfully transported to safety in neutral Sweden. In events set in motion from the invasion of 9 April 1940, through the summer of that year and the following year, a key role was played by a living charismatic leader, Hal Koch, and, through him, by his memorable nineteenth-century predecessor, N. F. S. Grundtvig. These remarkable events are properly to be contextualized not only in Danish history but also in the annals of nonviolent action as a path to the accomplishment of national goals.

\section{Grundtvig as the background figure who makes everything come together}

\section{Statement of the problem}

On 9 April 1940 the Nazi German invasion of Denmark precipitated one of the deepest crises in the many centuries of Danish history. The late spring, summer and early autumn of 1940, saw the establishment of a Nazi Occupation following the short but overwhelming invasion. During these tense and difficult months many Danes from all walks of life began to meet, discuss and plan for cultural resistance. ${ }^{1}$ Yet the contributions of two men, one living and one dead, are of special importance in understanding the events of this critical period; together they lit a spark which successfully catalysed the first phase of a broad and popular mobilisation for cultural resistance. (A distinction is often made between active and passive resistance; this topic will be taken up in the concluding section of the paper). ${ }^{2}$

\footnotetext{
${ }^{1}$ These meetings in the summer and autumn of 1940 are described in Nissen and Poulsen 1963, particularly in the first half of their detailed and welldocumented book.

${ }^{2}$ The relationship between these two forms of resistance, as well as the consequences of Koch's refusal to support active resistance, has received much discussion in the literature. See, for instance, Jørgen Kieler's essay in Goldberger 1987; and Frode Jakobsen 1986, 38-43. For reasons of space this paper
} 
This mobilisation for cultural resistance set in motion a powerful, underground revitalisation process which enabled the Danes to preserve their cultural identity even under the terrible, disintegrative stress of the Occupation years. If the initial mobilisation for cultural resistance had not taken place in the summer and autumn of 1940, there might have been no one willing to risk everything in a rescue operation when the hour of truth came for the Danish Jews in the autumn of 1943 .

The living man was Hal Koch, whose lectures at the University of Copenhagen in the autumn of 1940 gained him instant prominence as a spokesman for democratic Denmark. Standing somewhere at the lectern with him as he delivered his memorable lectures was the spirit of one of his predecessors, a man whose voice was not silenced with his death. His name is known to all Danes but few foreigners: N. F. S. Grundtvig (1783-1872). The contributions of these two men played a significant role in creating the later climate in which the rescue took place (the focus here is on the initial, take-off phase of a broader cultural mobilisation process, an initial phase which lasted roughly from the early summer of 1940 to the winter of 1942).

Through an analysis of the role played directly by Hal Koch and indirectly by Grundtvig, this paper will demonstrate that the events of the rescue had deep roots both in Danish democratic traditions, and in the unique and largely non-violent Danish path to modernisation which has been their fertile field for development over the past two centuries.

When the rescue effort is examined from the present vantage point of a half century, I would suggest that it appears not only miraculous but nearly incomprehensible. In the course of October 1943, 7220 of the approximately 7800 Jews then in Denmark were successfully transported out of Denmark to safety in neutral Sweden. Two questions are suggested here. First, how could the people in a little nation of Denmark's size, fewer than four million at that time, both organise and carry out a rescue action during which, in the space of less than a month, not just a dozen or a hundred, but 7220 people were first contacted, warned, hidden and given material support, then finally transported over both land and sea, in a network often organised by total strangers, to their final destination in Sweden? Moreover, all of this took place not only under the noses of the Nazi occupying power, but at the precise moment in time when it had directed its Prussian efficiency and thoroughness toward a single goal: the roundup, detention, and transport to mass murder of all the Jews in Denmark.

will focus on the events of the first year of the Nazi Occupation, and Koch's contributions during that critical period. 
It is often pointed out how spontaneous the rescue effort was. Yet it is rarely asked whether there were any cultural preconditions or historical background factors which facilitated that remarkable spontaneity. What were the psychocultural and psychohistorical factors behind the capacity for spontaneous, effective social cooperation so clearly demonstrated not by just a few, but by an overwhelming majority of the Danish people during the rescue operation?

The question of how it was possible for the rescue to be accomplished cannot be answered without posing a second, equally difficult question: why was it so important for the Danes, in their own minds and hearts, to protect and save the Jews who lived among them?

In no other European country subject to Nazi Occupation (with the possible exception of Bulgaria) did the persecution of the Jews meet with an organised resistance on the part of the native population that began on the first day of the Occupation and continued until its conclusion. Indeed, in many cases the persecution was wholeheartedly supported and sanctioned by powerful elements among the local nonJewish population. ${ }^{3}$

There is something strikingly different about the Danish response. Not only did the Danes in overwhelming numbers support the rescue effort, but many who participated did so at their own expense. They knew that their support for the rescue could have resulted in the loss of their property, their freedom or their lives. Why was it of such paramount importance to so many non-Jewish Danes to make these choices?

Why did they do so even in the full knowledge that the making of such choices would expose them to great personal risks? And given their choices and decisions, what cultural factors enabled them to act with the extraordinary degree of highly organised cooperation that made possible the rescue effort's success?

Even though we rejoice today in the memory of the rescue operation, we are much too inclined to take it at face value without looking very deeply into the social and historical process in which it is embedded. A closer look at some of the forces and trends in Danish life during the three years from the Nazi invasion of 9 April 1940 to the rescue actions of October 1943 will suggest that the successful rescue of the Danish Jews was by no means a natural or inevitable outcome. The developments in Denmark could have followed a very different pattern.

\footnotetext{
${ }^{3}$ The heroic actions of rescuers in other countries continue to merit attention. See Fogelman 1994. For an additional study with far reaching theoretical implications see Oliner and Oliner 1988.
} 


\section{The unique Danish path to modernisation: primary and secondary agents of transformation}

In order to document the continuity between the microhistorical events of the rescue effort and the broader background of the Danish democratic tradition, a brief historical overview follows. The Danish path toward modernisation was set in motion by three large-scale macrohistorical events, each of which constituted a major turningpoint in the development of Danish society. These turning-points, taken together, had as one of their major long-run consequences a profound widening and extension of democracy within Danish society. I have elsewhere (Borish 1991, 12) referred to these branch points in Danish history as "the primary agents of transformation".

The first of these macrohistorical transformations was connected with a series of magnificent and far-reaching land reforms which began in the later decades of the eighteenth century (they were not carried to completion until the second decade of the twentieth century). The second macrohistorical transformation was the peaceful ending of absolute monarchy and the acquisition of parliamentary government in 1848-49. A third macrohistorical transformation was the culmination of the thirty years' struggle over parliamentary democracy (1872-1901) which culminated in the political System Shift of 1901. ${ }^{4}$ The justification for calling these events "the primary agents of transformation" is that they appear to have been a historical prerequisite, a change in the baseline conditions of Danish society, facilitating and making possible the additional forms of democratisation that were to follow.

One truly remarkable feature has characterised the Danish path to modernisation. It is the ability to carry out far-reaching transfers of socio-economic power from limited social elites to wider groupings in the population without any large scale outbreaks of individual and social violence. Let me simply note here that each of the major social transformations described above was made possible by the predominantly peaceful and non-violent surrender of some of their power and privileges by ruling social elites. In the first instance, the social elite consisted of a class of major feudal landowners. In the second instance, it was a sitting Danish king who ruled in a tradition of absolute monarchy that had been instituted as far back as 1660 . Why, one must ask, did the same or parallel culture change processes that have so often resulted in violent repression both in the past (for instance the French and Russian revolutions) and in the present, occur without

\footnotetext{
${ }^{4}$ I wish to thank Flemming Lundgreen-Nielsen for pointing out this third primary agent of transformation.
} 
widespread social violence in Denmark? What is it about Denmark and the Danes that is responsible for this feature of their response to modernisation and culture change?

To treat these interesting questions in depth would require discussion beyond the scope of this paper. ${ }^{5}$ Yet in concluding this brief overview of the Danish modernisation process, an additional theoretical concept is required. From the last decades of the eighteenth century and continuing throughout the next century, the "primary agents of modernisation" encapsulated above facilitated the development of an interrelated complex of progressive social movements. Among them are the development of the agricultural cooperatives, the village meeting-houses, the independent church-congregations and free schools, the beginnings of social health insurance, the growth of the agricultural training centres and the rise of the folk high schools. ${ }^{6}$

Taken together these popular social movements can be called "the secondary agents of transformation". During an exceedingly difficult period in Danish history they gradually gained strength and accomplished a further democratic restructuring of many Danish institutions.

The history of Denmark in the nineteenth century, the period in which these progressive social movements both originated and flourished, can best be described as a series of catastrophes. A humiliating defeat at Copenhagen by the British in 1807 included the capture of the Danish fleet in its own harbour and its removal to England for safekeeping from Napoleon. Seven years of inflation followed resulting in a State Bankruptcy in 1813.

As a result of unfortunate participation on Napoleon's side in the Napoleonic wars, the vast northern nation of Norway, which had been in a semi-colonial union with Denmark for 400 years, was forcibly ceded to Sweden in 1814. In 1864 after a bitter conflict, the rich provinces of Slesvig and Holsten were surrendered to Bismarck's Germany. A pattern of epidemics and mass migrations - many to states of the American Midwest - followed. And yet, the slogan of another of the social movements of this period, the Danish Heath Society (Det danske Hedeselskab), sums up the Danish response to these harsh and crushing events. The movement's simple, eloquent slogan was "Outward loss, inward gain" ( hvad udad tabtes, det maa indad vindes).

${ }^{5}$ A deeper discussion for English-speaking readers can be found in Borish 1991, 1996 and 1998.

${ }^{6}$ The classic Danish treatment of these issues can be found in Skovmand 1951. Another important development in the path toward democratisation was the first provision of universal schooling, made possible by the School Reform of 1814 - this is well described in the work of Skovgaard-Petersen 1976. 
This movement, founded in 1866, was responsible for successfully reclaiming much of the barren heathland of Jutland for cultivation.

\section{The role of Grundtvig}

One cannot leave behind the rich and turbulent history of this period without at least mentioning the name of a remarkable man whose life spanned the greater part of it and whose influence on Danish institutions past and present has been subtle, powerful and sustained. Nikolaj Frederik Severin Grundtvig (1783-1872) was unquestionably a man of many parts: poet, historian, scholar, translator, educator, prophet, visionary critic of modern science as well as of the educational institutions and philosophies of his day, theologian, hymnwriter, protester, mythologist and mythmaker. If one were to sift through these times and search for the single person whose life and work left the deepest imprint on the Danish path to democratic modernisation, that individual would almost certainly be N. F. S. Grnndtvig.

"There is no man who ever became wise about something that he didn't first love" (Og han har aldrig levet, / Som klog paa det er blevet, / Han først ej havde kjoer). ${ }^{7}$ This is one of Grundtvig's countless zen-like aphorisms about the process of education. Upon hearing it one has sudden insights into an essential element in the life path not only of an Einstein, a Darwin, or a Van Gogh, but of all those who are fortunate enough to develop in some area of their lives "the art of craftsmanship". 8 One of Grundtvig's major contributions was to envision in the 1830s the founding of a "School for Life", a new kind of school to combat what he saw as "the black schools" of his day. The entire Danish folk high school tradition would grow out of these early visions. Education in its essence, he wrote, came from "the Living Word" (det levende $\mathrm{Ord}$ ), the intense conversation, the inspiring lecture, the spoken word (though he himself, in a paradox that is typical of the man, produced what if printed today would amount to nearly a hundred and fifty volumes of written words). ${ }^{9}$ Another of his contributions was the idea of the "People's Enlightenment" (folkeoplysning), which he saw as the deepest goal of all real education, that is, education that serves the purposes of life.

${ }^{7}$ From Grundtvig's song "Nu skal det åbenbares" (Højskolesangbogen, 2006, $88,5)$, which was drawn from the lengthy poem Gylden-Aaret (1834) (US, bd. 8, 10-25).

${ }^{8}$ For inspiration and a deeper discussion see Mills 1959, 2000, 195-228 (“Appendix On Intellectual Craftsmanship").

${ }^{9}$ This figure was given by K. E. Bugge, who has worked extensively with the Grundtvig Archive, in a lecture at the 16th CESE conference in Copenhagen, 1 July 1994. 
This partial and fragmentary summary does not even begin to do the man justice. ${ }^{10}$

What is the nature of Grundtvig's importance to Denmark today? In attempting to ascertain the precise nature of his influence, one runs into a surprising absence of direct signposts. As Kaj Thaning has pointed out, his works are not widely read even in Denmark. Little of what he wrote has been translated. Why then does Thaning (1972, 160) also enigmatically say of Grundtvig, "You meet him at the border"? Perhaps the best answer to this question has been provided by Povl Eller, former director of the Museum of National History in Frederiksborg (Det Nationalhistoriske Museum på Frederiksborg Slot).

There is a famous painting that hangs at this museum: Constantin Hansen's monumental rendering of the Assembly that drafted the first Danish Constitution (Den grundlovgivende Rigsforsamling) in 1848. Grundtvig appears in that painting to have been brought in as an afterthought, occupying a minor and modest place off to one side. Yet a closer examination reveals that the painter has placed Grundtvig right in the perspective vanishing point. As Eller has commented, "Grundtvig has been put in the main position. All of the room's lines meet directly over the crown of his head. It's not something that hits you in the eye, on the contrary, there's no one who discovers it" (Cited Wivel 1983, 23).

There are many places in Denmark where Grundtvig's painted or sculpted likeness appears, and few are the occasions in the folkekirke when at least one of his numerous hymns is not sung. Yet as Ole Wivel (op. cit., loc. cit.) suggests, it is Povl Eller's image of Grundtvig that perhaps best captures his importance both to Danish culture in general and to the rescue effort in particular. Grundtvig's place is somewhere off in the background, as in the monumental painting of Constantin Hansen. It is there - in the perspective vanishing point that his true legacy can be found. It is there that we shall find that legacy, playing both a literal and a symbolic role in the rescue of the Danish Jews.

To summarise: the thesis that I will develop here is that there is a direct relationship between some of the defining events of the historical modernisation process in Denmark, and the subsequent Danish ability to carry out the rescue of October 1943. This is a very large topic, and in this paper I will concentrate on just one of its many threads, the relationship between the wartime life and work of Hal Koch, and the mysterious, omnipresent pastor, N. F. S. Grundtvig.

${ }^{10}$ Fine selections of Grundtvig's writings for the English-speaking reader can be found in Bradley 2008, Jensen 2000 and Knudsen 1976. 
As befits one who dwells in the perspective vanishing point, Grundtvig will disappear for the moment only to reappear in a central role later in the paper.

There is nothing mechanical or automatic about any democratic tradition, whether in Denmark or elsewhere. Democracy is usually if not always an endangered species, and it must be renewed by effective and principled leadership in each new generation. It would be difficult to find a better example of principled leadership than the role played by Koch during the Nazi Occupation of Denmark.

\section{Hal Koch: A biographical note}

Who was Hal Koch? He was born on 6 May 1904 in Hellerup outside Copenhagen, and came from a family that had played a long and distinguished role in the religious, academic and business life of Denmark. He was an early rather than a late bloomer, a brilliant student quickly recognised as such both by his peers and his teachers. In 1921 he passed his Studentereksamen (upper secondary school leaving examination) and in 1926 he passed the University examination in Theology at Copenhagen with distinction and highest marks.

He spent the greater part of the next four years in international travel with extended periods of residence and study in three neighbouring European countries. When one considers the role Koch was to play in little over a decade's time, his particular choice of countries seems to have been guided either by Divine Providence, or by his own intuitive, preconscious genius. In 1927-28 he spent a year in Paris, studying the early Greek church fathers, especially Origen. But then after a brief return to Denmark in order to pass his examination in French, he spent the period from 1929 to 1931 in Germany and Italy, mostly in Tübingen. He became knowledgeable in eight languages about the early Greek Church fathers up to Athanasios, and Greek philosophy from Plato to Plotinus.

Koch's doctoral dissertation dealt with the relationship between Origen and Platonic philosophy. Completed in 1932, it was universally regarded as an outstanding piece of work. With his dissertation complete, he was qualified for a professorship in Church History, but the first one to become available would be four years later in 1936 . Moreover, it was defined in terms of Scandinavian church history, a topic that was not Koch's special field. Nevertheless, he threw himself into the task of mastering this field, and succeeded in an astonishingly short period of time in producing a number of publications that were regarded as significant contributions by all familiar with the field. In 1936, at the age of thirty-two, he was chosen over an older and more 
experienced competitor for the position of Professor in Church History.

From the very first, he was an outstanding teacher and many of the most promising students in the field came to work with him. Many outstanding dissertations were produced under Koch's guidance; yet he was also known as one who had time and interest for the "ordinary" student, including those who showed little aptitude for or even interest in his own field of church history. Vilhelm Nielsen, who worked closely with Koch during the Occupation years, has written: "I first learned to know him through his four semesters of lectures on church history. It was an experience that marked many of the listeners for life" (Koch, Lindhardt and Skovmand 1969, 70).

In addition to teaching and supervising advanced graduate work, Hal Koch continued with his own academic studies which resulted in impressive publications in different subfields of theology over a time perspective that ranged from early Greek antiquity to the late European Middle Ages. While working on this unusually diverse series of publications, he began to focus on the area of the Danish Middle Ages, starting to write a book that would be published in 1941. But already another subject had caught his attention: in 1939 he had begun a series of reviews of the newer literature dealing with the life and work of $\mathrm{N}$. F. S. Grundtvig. ${ }^{11}$ In that fateful year storm clouds were brewing not only over Denmark but over the whole of Europe. On 30 May 1939 Germany and Denmark signed a mutual non-aggression pact. Less than a year later, on 9 April 1940, the people of Denmark awoke to the sound of bombers droning above their cities, cannons being dragged across their fields, and tanks sitting in their streets and town centres. Almost overnight Denmark had been transformed from an independent democracy into an occupied power.

\section{Post-invasion crisis}

\section{The unusual features of the Nazi invasion}

In the months after the Nazi invasion of 9 April 1940, there followed a period of deep crisis and confusion in Denmark. The disintegrative impact of the invasion was felt in the streets and market places of Danish society, but perhaps more importantly, it was deeply felt in the private places of the Danish heart. Few in Denmark felt the pain of this collective wound more deeply than Hal Koch, and no one else could speak of what it now meant to be Danish with the clear, courageous

${ }^{11}$ Koch, Lindhardt and Skovmand 1969: see particularly the contribution by P. G. Lindhardt. 
eloquence that Hal Koch would soon manifest on the public stage. Before describing the role Hal Koch would play, we must appreciate the dimensions of the post-invasion crisis.

The Nazi invasion of Denmark had several unusual features, all of which contributed to the new and strange cultural climate that could be seen in the first days, weeks and months of the Occupation. First, the Danish armed forces were able to give only token, isolated resistance: and partly because of this, war was never officially declared between the two countries. In spite of the fact that no successful military resistance on the flat Danish terrain would have been possible, and that Danish politicians knew Britain and other potential allies would not or could not come to their defence, the quick and nearly uncontested surrender that took place was a painful blow to the national pride felt by the citizens of a small, independent nation. The mood of postinvasion despair is nowhere better expressed than by Koch himself on 14 December 1941 in a letter to his friend, the philosopher of religion and theology K. E. Løgstrup:

Haven't you cried, quite literally cried so it stripped away the skin, over the thing that has happened to us? Have you failed to understand that we lost our honour there, and that since then it has only been humiliation upon humiliation? [...] In the days after the ninth of April didn't you go and look around to see if there was one place in the country where in spite of everything someone had fought? Haven't you sat and wrung your hands because all was lost. Haven't you envied the Norwegians? (Nissen 1992).

A second feature of the invasion was its justification by the Germans on the grounds that an allied invasion of Norway was imminent, and that it was necessary for Germany to "protect" Denmark and the other Nordic countries from conquest by the allied armies. Denmark as a socalled "model protectorate" would be allowed to keep its King, its ministers and its Parliament. Even its army, navy and police would remain for the time under Danish control. The highest ranking German envoy, Cecil von Renthe-Fink, presented an official note to the Danish foreign minister demanding Danish acceptance of the German Occupation. The last sentence of this brazen note read:

In keeping with the good relations which have always existed between Germany and Denmark, the Government of the Reich assures the Royal Danish Government that Germany has no intention now or in the future of encroaching upon the Kingdom of Denmark's territorial integrity or political independence (Yahil 1969, 32).

The goal of this cynical strategy was to create a facade of cooperation in order to facilitate low cost utilisation of the Danish industrial base for the German war effort. Henceforth Danish industry, agriculture and 
transport facilities would be used to help Nazi Germany achieve both its war goals and (although no one knew this at the time) its goals of mass murder. In the same letter cited above, Koch agonizes: "No!!! That we directly and indirectly support and sustain Germany's war, and say yes to violence and injustice. And we could have said 'no'."

A third unusual feature of the invasion was that the invading Germans had positive racial stereotypes about the people of Denmark, whom they regarded as being fellow "Aryans" or as their "little Aryan brothers". The German soldiers had been told that they were coming to a friendly country, and to treat the population well. These three factors do much to explain why at least superficially and in its initial period the Nazi Occupation showed a "softer" face in Denmark. ${ }^{12}$ The positive racial stereotypes through which the Nazis (including Hitler) viewed the people of Denmark constitute an important factor that differentiates the invasion of Denmark from other Nazi invasions of the time; it gave the Danes an area of "cultural space" in which some potential manoeuvering was possible. Yet in spite of its misleading and deceptive mildness, its iron fist cloaked in a velvet glove, the Occupation unleashed both publicly and privately a set of negative reverberations that threatened to fundamentally alter, if not destroy, Denmark's democratic traditions and its proud sense of national identity.

\section{The anti-democratic forces and the threat to Danish cultural autonomy}

Let us examine these negative reverberations, taking as our time perspective the period between 9 April 1940 and the beginning of the new year in January 1941. First, let us remember how the world appeared to Danish citizens during the first few months after the inva-

${ }^{12}$ In both Denmark and Norway, the Nazi occupation was differentiated from the occupation of other European countries by the positive racial stereotypes; citizens in both Scandinavian nations were viewed as Aryan "younger brothers" who needed to be protected from British and Bolshevik contamination and properly "educated" as to their racial responsibilities. These images are strikingly reflected for the Norwegian case by the propaganda poster images for rallies and sports events, for example, showing a blond Norwegian youth shaking hands with a helmeted Waffen SS officer with a Viking ship floating in the mist behind them. See the remarkable colour images in Dahl, Hagtvet and Hjeltnes 1982, 176 ff. It is only by understanding the background of Nazi race ideology, which held that Danes were fellow Aryans, that Hitler's goal of making Denmark "a model protectorate", with its relative leniency at the outset of the Occupation, can be understood. See Hæstrup 1976, 9, and Poulsen 1995,10. 
sion. We who look back on that situation from a vantage point far removed in space and time will have great difficulty in understanding what it was like to be Danish in those first shocking days and weeks after 9 April 1940. To mention just one significant difference in perspectives, we know today which side was going to win the war. But in the spring of 1940, the Occupation of Denmark and Norway in early April was quickly followed by a series of successful invasions all over Europe. By the month of June Belgium, Holland, Luxembourg and even France itself had fallen to the Nazi armies. There was no visible prospect of an end to the string of German military victories, and in Copenhagen, in the "model protectorate", armed German soldiers could be seen walking freely about in the streets with the easy, insulting arrogance of conquerors.

A second area of reverberation stems from a situation with a much deeper time perspective, namely the ancient and at times bitter relationship with Germany. Although episodic in nature (for example, the Slesvig wars of 1848-50 and 1864), conflict with Germany has been part of Danish history for almost a thousand years. The sight and sound of German occupiers on Danish soil must have evoked a particularly Danish form of cultural nightmare: the subliminal fear that if the Occupation lasted long enough what it could lead to - and thereore what one might be witnessing in front of one's own eyes -was the effective end of Denmark as an independent national state, with the long-term or even permanent loss of Danish cultural autonomy.

A third area of reverberation, intermediate in its time depth, is also relevant. One of the most remarkable features of the rescue was the type of support it received from ordinary people within the general Danish population. In October 1943, the Danes were able to act with an extraordinarily high level of unity, cohesiveness and purpose. Yet if one looks at the political and cultural life of Denmark three years earlier, during the first days and months of the Nazi Occupation, there is little evidence of either cohesiveness or purpose, and unity is most conspicuous by its absence. True, a coalition government had been formed by all of the major political parties on 10 April, and a concerted attempt had been made among all mainstream politicians to present a facade of Danish unity to the high officials of the Nazi Occupation and to the public. But one did not have to look very far behind this facade to find a series of deep and schismatic splits existing within Danish society. These splits and their bitter, polarised factionalism had dangerously fragmented Danish political and cultural life. Their existence preceded the Nazi invasion but like an unhealed sore on which a jar of cultured virus is dropped, their post-invasion effect on the body politic was one of amplification and intensification. 
One area of split was in the relation between the mainstream Danish politicians from the post-invasion coalition government and "the man in the street". This split is perhaps best exemplified in the relationship between the political parties and their youth movements. In 1939, after proposing major constitutional revision, the social democratic party had suffered not only a loss of parliamentary seats but a loss of 30, 000 votes. Both its own governing coalition and the opposition parties were in political and spiritual disarray. No one talked much about it, but it was clear that those who had used systematic political violence and terror in neighbouring European countries had, at least in the short run, succeeded and prospered. This was true not only for Germany and Italy but for Spain as well. (In the case of Spain the antifascist movements did legitimate violence as a political instrument, but this did not prevent Franco from coming to power).

The example from the violent south had not been lost on the youth movements of the Danish political parties. One saw for the first time in the 1930s among members of Danish youth movements the wearing of blue blouses, shoulder straps and uniform. Some who belonged to the "agitation troops" of the conservative youth organisation had even taken to wearing high jack-boots, a practice from which a later jubilee review of the movement (covering this period) took apologetic distance, merely making the evasive comment that the boots "were more practical when the young people pasted up posters at night" (Nissen and Poulsen 1963, 26-28).

Nissen and Poulsen, the key Danish source dealing with these events, have commented:

When the atmosphere was one of battle, when uniformed corps with different party colours collided with each other, when the Conservative Youth Movement's Storm Troopers met the Social-Democratic Youth Movement's 'friendship-greeting' with the Nazi salute, and when parliamentary procedures were publicly dispensed with in the Conservative Youth Movement, one would have to make extremely subtle distinctions in order not to see this as an expression of the same movement away from democracy and parliamentarianism that already had triumphed farther south (Nissen and Poulsen 1963, 28).

In spite of the fact that a prohibition on uniforms had been enacted in 1933, members of these youth groups (particularly the Conservative Youth Movement and some of its more right-wing splinter groups) were actively trying to wear them (Kaarsted 1991, $121 \mathrm{ff}$ ). These and other signs of an uneasy identification with the successes of totalitarian governments to the south could be seen in Denmark even before the 
outbreak of war. In the intermediate aftermath of the Nazi invasion an even greater confusion and disunity was soon apparent.

A second area of deep internal division was the longstanding conflict between the rural and urban populations, and their institutional support groups. The depression of the 1930s had been catastrophic for the large numbers of farmers; many of them felt used and betrayed. Both German and Danish Nazis were well-aware of this second area of internal division, and did all they could to utilise the stereotypes and atmosphere of mutual suspicion in their propaganda after the Occupation. Their initial efforts met with considerable success. Within the space of two short months after 9 April 1940, one group, the Agriculturalists' Union (Landbrugernes Sammenslutning) had decided not only to cooperate with the Danish Nazi party but actually to become unified with it in a battle "against the existing political party system" (Nissen and Poulsen 1963, 71). It is true that the Agriculturalists' Union was not the most significant rural organisation, and that it stood as a protest movement against the much larger and more influential Agricultural Council (Landbrugsraadet). Nevertheless at its largest point it may have numbered as many as 36,000 members. An agricultural organisation with that membership, at this time, espousing these views, must be taken very seriously. ${ }^{13}$

The words of this resolution point toward the third dangerous area of schism in Danish society. The majority of Danish citizens, whatever their areas of disagreement, were ready to defend traditional Danish forms of democratic government (this larger grouping included most of those who were associated with the major political parties). But there was also a small but potentially influential minority whose reaction to the successful and largely unopposed German invasion was to blame everything that had happened on Denmark's democratic political structures. ${ }^{14}$ The leaders of these anti-democratic groups represented a reactionary and opportunistic force at the fringes of Danish political life, ready and eager to throw themselves into the spiritual power vacuum that was the immediate result of the invasion. To them the events of 9 April 1940 clearly showed that the institutions of political democracy had failed Denmark in its hour of crisis. It was democracy that had brought about a moral rot in the Danish national fibre; there was thus an urgent need to find replacements and alternatives for a failed democratic tradition. The voices of those in the antidemocratic movements could be heard loudly in the wings, manoeu-

\footnotetext{
${ }^{13}$ For a discussion of the youth movements of the time, see Kaarsted 1991 especially $121 \mathrm{ff}$., and Andersen 1976, $103 \mathrm{ff}$.

${ }^{14}$ Nissen and Poulsen 1963. See especially Chapter 5, "Antiparlamentarisme og genrejsere."
} 
vering their way toward the centre of the public stage in the spring and summer of 1940 .

One group among the anti-democratic forces was made up of a number of ultra-conservative opportunists with little or no practical experience in party politics. In the guise of responding to crisis, they sought to institute sweeping constitutional changes which would simultaneously have done away with the democratic political party system and increased their own access to power. Furthermore, these desirable goals would be accomplished without the bothersome inconvenience of having to go through an electoral process. The Højgaard-circle, named after its chairman, engineer Knud Højgaard, was one group belonging to this category. In an interview with the magazine Børsen on 6 August 1940 Højgaard made clear his views on democracy, declaring that "there is no sense in having people who can't handle their own affairs participate in deciding who the leadership of the country will be" (Nissen and Poulsen 1963, 85).

Another who belonged to this category of anti-democrat was Supreme Court attorney Leif Gamborg, who remarked at a wellattended summer meeting at Gerlev Folk High School in mid-August, 1940:

It is mere superstition that the practical importance of the Parliament is so great. It is a terrible waste of words and time [...] the men of the System cannot continue. Those who have built the System up do not have the ability to change it in accordance with the demands of a new time (Nissen and Poulsen 1963, 88).

He went on to suggest that the ministers of government, instead of being appointed by the parties represented in the governing coalition, should be directly appointed by the Danish King. Once this change was instituted, a stable situation would result and the political parties would lose both their meaning and importance. From which social groups should the ministers come? On this question Gamborg was perfectly clear: "It is the men of industry who must now be chosen. The System will come of itself' (op. cit., loc. cit.).

A second group among the anti-democratic forces was made up of a group of Danes who believed the invasion showed that Denmark had a lot to learn from Germany. The logical consequence of this view was that the Danes should seek to emulate the Nazi Occupying Power in important cultural areas. Included among the members of this group were some with the potential to play a highly influential leadership role.

In August 1940, Niels Bukh, the well-known and highly respected principal of Ollerup Physical Education College (Gymnastikhøjskole), drafted an extensive plan for the formation of a new Danish youth 
organisation. The first step would be to join together four large unpolitical organisations in the area of sports and athletics. Bukh proposed that after a short transitional period, the four clubs would disappear into the new organisation on a permanent basis. But even this new structure would just be a beginning; other youth organisations would subsequently be merged with it. "This organisation must become the only state-recognised and state-supported athletic organisation in Denmark," wrote Bukh (Nissen and Poulsen 1963, 90). He justified the centralisation and the monopolistic organisational structure in terms of effectiveness: savings of fuel and light, better utilisation of playing fields, and so on.

This idea of a single centralised youth club was in essence a statesupported monopoly on the physical training of youth. It did not seem like a Danish idea, and indeed it wasn't. Its unmistakable origin was in ideas and practices that had come from Nazi Germany. In the years after 1933 the Hitler Youth had functioned in Germany as a statesupported, monopolistic youth organisation whose overriding purpose was to incorporate and indoctrinate adolescents into the so-called Volkgemeinschaft ("racial community"). ${ }^{15}$ The goal of National Socialist youth policy was

to secure the younger generation's total loyalty to the regime and their willingness to fight in the war that lay ahead. All competitors had to be eliminated and Nazi forms of organisation and militaristic education developed (Bessel 1987, 26) [italics added].

That such a state supported monopoly was now being proposed by Niels Bukh, the same Niels Bukh who as Denmark's leading gymnast had led the Danish gymnastics team at the Olympics in Berlin in 1936, was nothing less than ominous to many observers. Bukh had said at the time:

${ }^{15}$ This translation of Volkgemeinschaft as "racial community" is only meant to represent the deeply flawed meaning of the term in Nazi racial ideology. Seen from our contemporary point of view, it is biased and loaded, shocking and irrational (not to speak of its fundamental misrepresentation of what Stanford biologist Paul Ehrlich has referred to as the patterns of discordant variation that characterise human biological diversity). For us the term Volk usually conveys the sense of "folk" or "national" and indeed for Grundtvig (and most Danes today) the term folkelig and its uses has nothing whatsoever to do with ideas of race or other metaphors used to make invidious group comparisons. The more limited goal of the above translation is only to provide what anthropologists would call an emic insight into the deluded thought-world of the Nazis (and the equally deluded contemporary practitioners of racism and race hate). 
I was pleased with my visit to Berlin and Nuremberg and the other places we visited, and I still think, without in the least being a Nazi, that we have much to learn from the New Germany's cleverness, solidarity and willingness to sacrifice (Nissen and Poulsen 1963, 92).

These remarks had been made in 1936, after his German visit with the Danish gymnastics team. Bukh had attended the Nazi Party Congress in Nuremberg, and had even met Hitler in person while at these events. Even more significant is the fact that as late as 1941 he was still expressing the view that the German military's respect for the flag was something that Danes should seek to emulate. In the late summer of 1940, Bukh's plan for a single, centralised, government-dominated youth athletic youth organisation was being seriously discussed in the Danish press. It needs to be pointed out that Bukh at the time enjoyed an unopposed reputation as the first man in Danish gymnastics, as one who through tours over the entire world had made Denmark's name known. ${ }^{16}$

A third anti-democratic force consisted of those who, while belonging to mainstream political organisations, actively sympathised with the anti-democratic arguments and attempted to steer their organisations in this direction. Reference was made above to the Conservative Party's youth movement, whose members had taken to wearing high jack-boots and party uniforms in spite of fierce and determined opposition by party chairman Christmas Møller. The Conservative Youth organisation had two wings, one openly admiring the results of Nazi and fascist methods, the other strongly opposed. In the wake of the invasion, leading representatives from the youth organisations of all the major political parties began seriously to discuss the possibility of mutual cooperation. But Leo Dane, the national chairman of the Conservative Youth Organisation, stood in determined opposition; Dane was an acerbic and uncompromising leader of the extreme rightwing faction.

On 24 April, two short weeks after the invasion, his article in the Youth Organisation's magazine opened with these inflammatory words: "On the 9th of April the Conservative Youth Organisation was shown to be right about everything that our movement has maintained about the country's irresponsible and decrepit rulers." (Nissen and Poulsen 1963, 39-41). But Dane went even further. He insisted on labelling the Social Democrat and Radical Liberal politicians who held power the day of the invasion as traitors to the country. He bitterly

\footnotetext{
${ }^{16}$ The definitive work on the athletic tradition in Denmark, including the Physical Education College (Gymnastikhøjskole) from which Bukh rose to prominence, is Korsgaard 1982. See also Korsgaard 1997 for a broader treatment of the tradition of adult education in Denmark.
} 
accused those within his own party who were willing to cooperate with them (the other wing of the Conservative Party was led by Christmas Møller, who would later be forced to flee the country to England and through his radio broadcasts become one of the leaders of the Danish resistance movement). Dane proposed that the Conservative Youth Movement dissolve its connection with the Conservative Party, and go in the lead to work for a national youth front. The goals of this front would be a bitter showdown with the accommodationist line, a humiliation of the mainstream leaders who supported it, and ultimately a complete realignment of political power within Denmark. Those who stood to benefit from this realignment belonged to a branch of the radical right wing that had already made clear its sympathies to Nazi goals and methods.

Dane was one of those who was convinced that the Germans would win the war. In the issue of the Conservative Party youth magazine for 15 June 1940, he flouted established organisation policy. In a perfect example of anti-democratic attitudes reflected in antidemocratic practice, Dane published his own program without ever including a statement that he was speaking for himself and not for the organisation. Under the headline "Young Danish citizen, know your Time!" he wrote:

We do not merely have contempt for, no, we hate and are revolted in our honest Danish heart by that radical-socialism that has led our people to degradation. The apostles of class-hatred, materialism, godlessness and anti-nationalism will never be granted our forgiveness (Nissen and Poulsen 1963, 74-75).

He proceeded to give a deeper elaboration of his cultural indictment, pointing out a new source of betrayal:

\begin{abstract}
We conservative youth movement members are young Danes. What does that mean now, some of my readers will ask? It means a bridge and a front: a bridge to some of the values of the Danish people that are worth saving: our monarchic form of government, our church, our true and original Danish cultural foundation liberated from the last three quarters of a century of Jewish-radical influence. But also a front: hard and unbending against all of the forces that then as today are subverting the Danish people (op. cit., loc. cit.).
\end{abstract}

These lines went too far. Dane's attempt to lace his anti-democratic views with anti-semitic sentiments alienated even most of his supporters in the Conservative Youth organisation. But compared to the written statements and public speeches that could be heard coming from the Danish Nazi party, his views were quite mild. It ought to be remembered that the Danish Nazi party had succeeded in getting over 31,000 votes in the 1939 election. Both its leader, Frits Clausen, and 
two other party members were voted into the Danish Parliament. And in the months after the invasion the Danish Nazi Party (D.N.S.A.P.), led by Frits Clausen, held numerous public meetings all across Denmark, gaining both new members and new sympathisers. On 17 June it was joined by the Agriculturalists' Union in a battle against "the existing political party system". On 25 June there were Nazi demonstrations in Roskilde, and in the ensuing battles with Danish police German soldiers appeared on the side of the demonstrators, giving an ugly portent for the future.

Clausen's party was not the only active Nazi party in Denmark at that time. Even as late as the autumn of 1941 there could be found at least a dozen recognised Nazi parties and splinter groups. Wellfinanced by representatives of the Nazi Occupation, such magazines as Kamptegnet and Faedrelandet poured out a ceaseless stream of Nazi propaganda equal in the viciousness of its racial caricature to the worst that could be found in Nazi Germany itself. "One doesn't speak with Jews, but about Jews." "The Jew is the cancer cell in society." And worse: "No peace on earth as long as even one Jew is alive" (Prieme 1982, 56 ff.). An energetic attempt was made to convince the average Danish citizen that the Jews not only controlled the Danish economy but were in addition the secret leaders of the government. Each week these magazines published lists of Danish firms that had hired Jews, and under the headline "Race Dishonour" they published the names of newly married couples in cases where one member of the pair was not Jewish. In Copenhagen the Biographical Institute (Personalhistorisk Institut) issued attestations of Aryan racial standing using the same questionnaire employed by the Nazis in Germany (Segal 1991, 25). Later a so-called Danish Freedom Brigade (Frikorps Danmark) would be sent to the Eastern Front, and the "HIPO" (Hilfspolizei), an auxiliary Danish-German police force which included some seven hundred Danish Nazis, would be used to terrorise the population and hunt down members of the resistance movement (Goldberger 1987, 139).

I have attempted in this section of the paper to describe some of the anti-democratic forces that were active on the Danish landscape in the atmosphere of crisis and confusion that came after the Nazi invasion of 9 April 1940. In the spring and summer months that directly followed the invasion, these forces were gaining in momentum. In view of the facts just presented, let us ask the following questions. What would have happened if the Danish Nazi parties had continued their sharp rise in popularity and membership? If Leo Dane's views had prevailed in the Conservative Party's youth organisation, and the anti-democratic front for youth he envisioned had gained widespread support? If Niels Bukh's plans for a single, centralised, state- 
controlled monopoly on youth athletic organisations had been realised? If the Højgaard group had been able to realise its plan for a de facto return to monarchical government, in which power would be held by an unelected political élite directly appointed by the King? What would the implications have been for Danish democratic traditions? For the Danish ability and the Danish desire to protect the Jews within Danish borders from the gas chambers of the Final Solution?

These questions fortunately remain hypothetical largely because of a remarkable series of events that were soon to take place. By the early winter of 1940-41, the Danish Nazi party, which had gained so many new members in the summer and autumn of 1940, had visibly stagnated. Resignations soon followed from the Nazi-allied Agriculturalists' Union. Under pressure, Leo Dane was forced to resign his position as national chairman of the Conservative Youth Movement. Niels Bukh's plans for a single centralised sports organisation for the youth never materialised; nor did the Højgaard group's plan for a summary return to monarchical government (a first attempt in this direction was summarily dismissed by the King himself on 14 November 1940). The anti-democratic movements, so visible and encroaching in the first post-invasion months, were now on the defensive. Why had the tide so quickly and definitively turned? In the critical months between the late spring and summer of 1940 and the arrival of January 1941, something of great importance had taken place.

\section{Hal Koch: time of destiny (1940-41)}

The early autumn of 1940 would be a time of destiny for Hal Koch. In the space of just a few weeks in September he would be transformed from an obscure Professor of Church History to a national figure on the highest level. He would become the national Chairman of the Union of Danish Youth (Dansk Ungdomssamvirke), an umbrella organisation of young people from the major political parties deliberately created to mobilise cultural resistance throughout the general population. ${ }^{17}$ Yet it is difficult to imagine a more surprising and unlikely figure to play a central leadership role in a time of national crisis. Few in Denmark knew who he was as little as a month or two earlier. For prior to this time Hal Koch had taken no part in public life, either in politics or in the work of the ubiquitous Danish voluntary associations. He had never given a single public lecture outside of the university, nor had he written columns for the news-

17 An in-depth treatment of the origin of the Union of Danish Youth, including Koch's role, is given in Nissen and Poulsen 1963. 
papers. It is not an exaggeration to say that he was an unknown figure outside of the small, intense world of the university.

Why did Hal Koch abandon the comfortable anonymity of his professorial position and step forward to claim a public role? In order to follow the events of September 1940, one has to try to understand what happened to him in the weeks and months that followed the 9 April invasion. There is much evidence to support the view that even more than most citizens of Denmark, Hal Koch was devastated by the Nazi invasion, and in its aftermath he suffered a crisis of despair in which his soul was blasted and burned from within. He was driven to act as he did both out of his despair and out of his terrible sense of shame and betrayal.

Consider, for instance, this picture of him given by his close colleague Vilhelm Nielsen:

My thesis is that what happened that day [9 April] shook him to the roots, or somewhere deep in the very foundation of his being, in a place that he had never before recognized or been conscious of, and that he neither at that time or later liked to talk about much [...] $\mathrm{He}$ experienced a deep sense of his roots that in many ways was liberating, but its first effect upon him was to unleash a sense of irresolution and despair (Koch, Lindhardt and Skovmand 1969).

What were Hal Koch's roots? He had a deeply personal relationship with the Christian tradition in which he had been reared, and which he had chosen to study as his life's work. He was also, in every inch of his being, a proud Dane who had seen Denmark humbled in front of his eyes. He was one of those who passionately felt that a terrible mistake had been made on 9 April, that Denmark should have raised the sword back to the Germans on 9 April, and that this should have been done whatever the cost and even though one knew in advance that the battle was hopeless. The knowledge that this chance had been lost, that it had come and gone on that day and now had passed by for good, was bitter beyond words for him.

When he recovered from his initial irresolution, Koch came to believe that his responsibility was to support the King, the government and the Parliament in their bitter task of negotiating with the agents of the Nazi Occupation. The only honest thing to do was to accept the reality of the present situation, to take upon oneself all of the bitter consequences of that failure to fight back. The task now was to mobilise the people in support of their present government, to defend the institutions of Danish democracy against the emerging anti-democratic forces, and to enable the Danish people once again to believe in themselves. Koch had a rare configuration of character traits, combining a high idealism with the ability to see events from the point of 
view of the pragmatic tactician. As he wrote in his reply of 14 December 1941 to one of K. E. Løgstrup's bitterly critical letters:

Just get away from me with your nonsense about the absolute and Danish politics. It's not the absolute that matters here. There's only one thing that matters now: to build up those forces that may still be in reserve, to prepare with the coming battle in front of our eyes (Nissen 1992).

In order to prepare for that coming battle, he decided to offer a series of ten lectures at the University of Copenhagen in the autumn of 1940. The announcements stated that these lectures were not aimed at any particular department or faculty within the university, but would be of a more general nature, open to everyone. No one, including Hal Koch himself, could have anticipated the impact these lectures would have on the entire subsequent history of Denmark under the Nazi Occupation. After his first lecture on 18 September 1940, the following lines appeared in the review given by Berlingske Tidende (the major Copenhagen daily):

Yesterday afternoon the appearance of the university courtyard was the prelude for a sensational première. Three broad lines stretched out toward the entrances to the University Annexe, two from the street, the third and largest, composed of young students, outwards from the courtyards door [...] It is estimated that in Auditorium A - the auditorium for thesis examinations, where the lecture series will be held - there were at least five hundred people. Of course, there were not nearly enough seats. People stood like herrings in a can along both sides of the auditorium, and the young female and male students were packed so tightly, that it was difficult for the Professor to make his way up to the speaker's place when he came into the room (Nissen and Poulsen 1963, 130-131).

It was anticipated that the number of spectators would begin to fall off when Koch came to hold his second lecture the following week. Instead, an even greater number of people came to listen to him. It was decided to hold each lecture not once but twice. And still the lecture halls continued to overflow each time, and there were many who tried in vain to gain admission to both lectures. Koch's first lecture, reprinted in its entirety, took up two full columns in the next day's edition of Berlingske Tidende. And even though his second lecture a week later was given on the same day as King Christian VII's seventieth birthday, it received the same two column treatment from the newspaper.

Hal Koch's first lecture is regarded as one of the great classic documents of Danish history during the Nazi Occupation years. It is a text that entered instantaneously into the waiting hearts of his country- 
men. Taking place decades before our McLuhanesque age of electronically amplified information transmission, Koch's first lecture nevertheless became a part of Danish history on the very same day that it was spoken in the lecture hall. The effect that this lecture and the many that followed had on his countrymen is not easy to describe. It did not light under them the hot fire of rage that leads to immediate and perhaps premature action, and in whose wake there may be left only a collection of burnt ashes. Rather what it seems to have done is to have lit in them the cool fire of determination, and to have given them the pride, energy, and persistence to look deeply into themselves and their own cultural traditions for guidance and inspiration in this time of deepest national crisis.

The first lecture of the autumn series was of paramount importance. A few citations will convey something of its spirit. Koch begins by observing that the audience of students he is now addressing may have better material conditions than the students in most other European lands, but that they nevertheless are suffering inwardly from feelings of anxiety and indecisiveness, from a severe disconnectedness. The reasons for this are clear:

[...] because our land and our people have become a plaything for great powers - not for greater powers, as it is so often said, but for violent forces that threaten our entire existence. And when we say existence we are not thinking of business and industry, agriculture and other commercial enterprises, nor are we thinking of the food we eat or the clothes we wear. We are speaking of our Danish kingdom, of our people and our language, the root from which we come, the little piece of earth to which we are bound. If you have not felt that anxiety, if you are not tormented by fear and irresolution all the way down to the bottom of your soul, then you are of no use for anything other than to be thrown out and trampled upon (Koch 1943).

Koch's rhetorical arguments were often very subtle. Note that he is not only speaking here to feelings of anxiety and confusion, but in an exceedingly sophisticated way is both reaffirming and validating these feelings as a necessary precondition for further action. He goes on to say:

Our sorrow is turned backward toward misused time and destroyed possibilities, and our fear is directed toward the days that come - but first and foremost it is time to battle, and the name of the battle is Denmark, and it begins in our own heart here and now.

He introduces in this first lecture a theme that will come up again and again in his talks, a critical warning directed against the quick and easy prescriptions made by those in the anti-democratic movements: 
From outer causes alone are things ordered in such a way that now is not the time to give a loud shout and make grand gestures, and I warn you against the many who are preaching that the hour is ripe for great actions, now, at a time when we are not the masters in our own house.

In a lecture entitled "Reality" given during the same week at the Christian Academic Association, he made an even sharper attack on the anti-democratic leaders:

I will not talk politics, but I warn you against letting yourselves be carried away by the many powerful and splendid fellows who suddenly have come forth, all of whom can hold doomsday sermons about the past and its men, but who themselves were never able to lead us down another road in those same days. They have not seen the visions but they are small and narrow in their souls, and they live high by tearing the others down. It is not there, our insight and our future will grow.

This lecture repeated the call to look inward and face the harsh truth of Danish life at that moment:

If you now for half a year have swung from an indignant fury, which in its powerlessness knew no remedy and no escape, to a quiet, obstinate energy, and further to a weary hopelessness and lack of courage, then you know a little about what the spirit is. If you have felt that there is now only one thought that awakens with us in the morning, that follows us through the actions of the day and fills our minds when we turn in in the evening, then you know a little about what the Danish spirit is. And if it is not like this for you, then I can spare you the rest of what I am going to say.

The initial lecture series beginning in September 1940 at the University of Copenhagen quickly gained Koch a national reputation. Printed as newspaper columns, they were appreciatively read and widely disseminated. Although the University of Copenhagen lectures are probably the best known and the most highly publicised of his talks, he gave many other memorable lectures during the same time period. And even these lectures taken together were only the smallest beginning of his dedicated public activity during the coming crucial years.

On 20 November 1940, Koch was offered the position of Chairman of the Union of Danish Youth, the umbrella group that would bring together representatives from the youth movements of the political parties in an attempt to transcend their differences and work constructively together during the Occupation years. In its monthly magazine Lederbladet, received by thousands of youth leaders across the country, he was the one who wrote the decisive articles, and his lectures in nearly every town in the country over the course of the next three years bore the stamp of authority. They were powerful, clear and effective lectures, which resonated long afterwards in the hearts of 
those to whom he spoke. Nielsen, who travelled with him countless times during these years, writes: "There is seldom much discussion after Hal Koch has spoken" (Koch, Lindhardt and Skovmand 1969). After he had spoken in one small town on the island of Fyn, an eloquent and revealing comment was made in the town newspaper the next day: "It was as if one left Fyns Forum with a straighter back than one had had before coming there" (op. cit., 108).

In the months that followed his selection to the office of chairman of the Union of Danish Youth, he began an additional series of lectures that would take him to every district and nearly every town and village in Denmark. One of his popular lectures dealt with the history of Denmark in the twelfth century, a time when Denmark had also been threatened by German domination. Koch would begin by saying, "The subject is so relevant that one hardly knows if one dares allow the events to speak their own language." A second popular lecture made the point that democratic institutions were not something new or imported in Denmark. Their time of origin, Koch reminded his listeners, was not 1849 or even 1789 , but could be traced back to the old tinghus of the early middle ages. All later manifestations of democracy, he argued, were based on a rebirth of this tradition that had been lost for the intervening centuries.

He never spoke down to his audiences. Nor did he offer them the easy, marshmallow clichés that are the life blood of demagogues, for example, the idea that the past can provide easy answers for what we should do now, faced with our present problems. Koch would say instead that the differences between the past and the present were in spite of everything larger than the similarities, but that one could learn to act in a spirit that the ancestors would not have been ashamed of. $\mathrm{He}$ was speaking in the darkest winter of the war (1940-41) in the face of a Germany everywhere triumphant and at a time when the most important fight was the struggle against inner surrender, against giving way to apathy and hopelessness. Yet even in these times Koch remained an unvarnished truth-teller. He always began with the harsh reality that faced them, and never wavered from his insistence that his audience must see clearly everything that it implied:

We cannot turn to the past, indeed we will find there no grounds for blue-eyed optimism. We cannot gain from the past a belief that everything will soon be again as it was, for there is no ground to believe that what we are faced with is a temporary storm. It is possible that it will not be us who come to experience the new time. But we still can learn from our history, how once in difficult times men stood at each other's sides and stone was laid upon stone. Let us go the way together without looking to the side whether or not we come to harvest the reward [...] And let us remember that the future of Denmark is built up 
not out in the great world, or in the words spoken at meetings, or in the columns printed by newspapers, but it is built up in and by each one of us, each individual among us, and every time one of us fails, there is an empty place in the line. This is what the Union of Danish Youth is trying to say to you: we walk the road together (Nissen and Poulsen 1963, 145).

One is amazed by the seriousness of his words; they come at you like bullets driving down and through the smokescreens of fear, confusion and denial to touch you someplace very deep inside. This was his genius, that he could speak as a voice of authenticity driving home the deepest and most essential truths to Danish men and women. He could communicate effectively not only to students and professors, but to farmers, factory workers, clerks, shopkeepers and fishermen. He spoke with the compelling personal honesty that was his gift of character. Aided by his other gifts of language and learning, he seemed to be able to distil and crystallise out of his vast erudition exactly what had to be said to evoke for Danish men and women a true sense of the seriousness of the situation that faced them. What he told them in the compelling language of the heart was that it was up to them, by their own actions, to save Denmark's honour, its traditions and all that was best in its unbroken cultural heritage of more than a thousand years.

He travelled, lectured and performed community action work unceasingly for the next three years, taking just an occasional week off, unfazed by the fact that his life was increasingly in danger. His travels took him back and forth across the whole of Denmark. He came to be seen in the public eye as not only the leader but the quintessential voice of the Union of Danish Youth. During this time both the German and Danish Nazis were planning his assassination, and in the meantime they did all they could to silence him by threats, censorship and printed character attacks. A bomb meant to assassinate him was placed on the front door of his house on the night between 12 and 13 June 1942, but due to faulty timing it exploded before his return and no one was injured, although there was considerable property damage. The Nazi magazine Fcedrelandet took the part of the bombers, commenting:

Hal Koch has challenged fate for a long time, and one day things will go wrong. Sooner or later Hal Koch will get the reward he deserves for the gospel of oppression that he preaches under a false flag at the meetings of the Union of Danish Youth. Unfortunately it will be those who have allowed their indignation to result in rash deeds who will come to pay a price for their recklessness. They will be punished, even though those bearing the real guilt are none other than Hal Koch and the circle that follows him. 
But by June 1942 the anti-democratic forces, including the Danish Nazis and their sympathisers, had been reduced to the status of a despised and dishonoured minority. No one outside of their own ranks, not even the powerful figures in the Nazi Occupation, was taking them seriously. At least a part of the credit for this state of affairs must go to the steadfastness, the dedication and the insight of Hal Koch.

\section{Concluding reflections}

The treatment given in this paper of Hal Koch's role is of necessity a partial one. It has focused on his rise to power and initial triumph in the cause of mobilisation for cultural resistance. A more complete treatment would have to include some of the difficulties that came as a result of the early successes I have described. Yet what I would like to do now is leave behind a narrow historical exegesis and reflect on some of the broader issues that I believe are implied in this discussion. I am a specialist neither in the history of modern Denmark, nor in Denmark under the Occupation. It is therefore with a certain amount of trepidation that I shall lay out an interpretation of the events of this critical period 1940-1943.

The distinction between passive and active resistance is valid, and part of its validity comes from the fact that it was made by those who lived through these events. ${ }^{18}$ Yet looking again at these events as an outsider and as an anthropologist, I would like to suggest that what is also of interest here (and of great relevance to the rescue effort of October 1943) is the total, overall pattern of cultural resistance to the Nazi Occupation developed in Denmark between the summer of 1940 and the summer of 1943. It is this total, overall pattern of cultural resistance, a pattern of which the passive resistance is also part, that created the climate in which the rescue of the Danish Jews could take place. From this outsider's perspective, what have been called the "passive" and "active" forms of resistance look more like phases of a single cultural process, the "passive" forms being primary in the period from 9 April to the summer of 1942, the "active" forms taking over primacy certainly from that point and continuing to the end of the Occupation in May 1945.

I would like to clarify this argument by turning to that interesting and subtle class of historical questions which sometimes cannot be

\footnotetext{
${ }^{18}$ The path taken by Koch and the Union of the Danish Youth, built around a national campaign to inspire and rebuild faith in the Danish identity, is customarily referred to as "passive" resistance. The path taken by the resistance groups, which included the illegal press, radio, rescue, courier and sabotage actions, together with an underground army, constitutes "active" resistance.
} 
definitively answered, yet which still must be asked. One of them is this: what was the single most decisive turning point in the emergence of the Danish capacity to resist the Nazi invasion? That the Danes did display a capacity to resist the Nazi invasion is a matter of the historical record. And few will argue with the conclusion that this capacity for cultural resistance was a prerequisite for the successful, non-violent action of mass civil disobedience resulting in the rescue of the Danish Jews that took place in October 1943. But the growth of this capacity for such focused and cooperative resistance to an occupying power was not at all inevitable. Nor was the rescue of the Danish Jews.

The contribution made by Hal Koch, especially in the initial period from the early autumn of 1940 to the summer of 1941, may well have been of such fundamental importance to the mobilisation of Danish cultural resistance that merely to call it "passive resistance" does not do it full justice. As I have argued earlier in this paper, it is possible to envision quite another scenario, in which the Danish Nazis together with the Germans were able to exploit existing divisions to create a powerful fifth-column within Denmark, eventually making it impossible for the rescue to have taken place. Remember for a moment the spiritual confusion and despair that existed on the Danish landscape in the weeks and months after 9 April 1940: the anti-democratic Højgaard circle, Niels Bukh's plan for a single, state-supported athletic organisation for the nation's youth, Leo Dane's attempt to start a reactionary, pro-Nazi youth front, and the various Nazi parties, splinter groups and their supporters. These and other anti-democratic forces flourished opportunistically during the spring and summer of 1940. Yet by the early winter of 1941 they were a spent force, a collection of empty barrels that made a lot of noise but that almost no one was taking seriously any longer.

I want to suggest here my growing suspicion that if a turning point, the real beginning of the emergence of effective Danish cultural resistance, can be identified, it may well have been the very first lecture given by Hal Koch on September 18, 1940 (though the remaining nine lectures in that series were also of great significance). Now this interpretation of these events is certainly open to debate, but if it has even the slightest degree of truth, then the topic Koch chose for that first lecture at the University of Copenhagen on 18 September will be of considerable interest. It was the beginning of the autumn term just five months after the German invasion. Faced with the need to give a series of talks which would remind the Danish people of who they were, which would bring them face to face with the best in their own cultural tradition, what did Koch choose to be the central topic of his 
lectures? With all of Danish history from which to choose, what did he select as the unifying theme to bind all of these lectures together?

He chose as his topic the life of N. F. S. Grundtvig, the great nineteenth-century man of letters who more than any other figure from the past connects each living generation of Danes with the unique Danish path to democratic modernisation. At the outset of the first lecture he told his audience:

We have woken up confused and insecure about the very simple task of what it means to live a Danish human life [...] Now is the time for you and for us all to reflect on our lives as human beings and as Danes. Many are calling for action, but a true knowledge of ourselves and the present circumstances of our lives is the necessary and unavoidable precondition for true and authentic action. And the road that leads to this goal is both steep and full of stones [...] In Grundtvig you will meet a man who has wandered this road and for that reason was better able to speak truly and honestly about reality [...] For him being human was inextricably connected with being Danish, and nothing that he has sung or written does not reflect this [...] Therefore we listen to his song: not in order to repeat or to imitate it, but because the ancient singer, life's true visionary, can cast light on that path which just now is knotted and difficult to unwind.

Was it by some fortunate coincidence that in 1939, just a short time before the Nazi invasion of Denmark, Hal Koch had begun to review the contemporary literature on Grundtvig? Whatever the reason, with these impressions fresh in his mind it must have seemed natural for him to choose the life of Grundtvig as the unifying and underlying theme for his lectures in the autumn of 1940. Grundtvig's views on freedom and human life, his ceaseless quest for truth and enlightenment, and his love of and obsession with rebuilding the Danish language and culture in the difficult crises of his own century, were precisely what the people of Denmark needed to hear during their own dark time. Hal Koch once asked his audience: "Can one in any other land find a single person, who has set so deep a mark on the life of his people?" He used his ten Grundtvig lectures to remind the Danish people of their own cultural heritage, and he did it with flair, with brilliance and with passion, at the very moment in time that the Nazi war machine was at the high point of its success, destroying European democracy and attempting to remake a large group of captive nations and their captive population in its own image of the racial state.

I cannot forget Hal Koch's words to K. E. Løgstrup (cited earlier in this paper): "It's not the absolute that matters here. There's only one thing that matters now: to build up those forces that may still be in reserve, to prepare with the coming battle in front of our eyes." 
When the battle came, the forces still in reserve had not been lost to apathy or despair. The rescue of the Danish Jews took place because the Danish people knew who they were. All the Nazi propaganda had not been able to take that away from them, had not been able to instil in them the hopelessness, depersonalisation and fragmentation, the schizoid sense of alienation and isolation from humanity, that the Nazis had been able to instil in the great majority of people whose lands they occupied during these years. The Nazis failed in their mission in Denmark. The Danish people had kept their democratic traditions alive, and the Jews became a living symbol of that tradition. The life and work of Grundtvig served as a living link between the demands of the present and the achievements of the past, in particular the events of the late eighteenth and nineteenth centuries connected with the unique Danish path to democratic modernisation. Indeed, one can hardly imagine a more profound realisation of Grundtvig's ideas of "the Living Word" and "the People's Enlightenment" than the early wartime contributions made by Hal Koch. And yet as befits one who dwells in the perspective vanishing point, Grundtvig's inspiration goes even further: the movement which conducted active resistance and sabotage against the Nazi Occupation until the end of the war named a major strategic document "the Grundtvig plan" (Grundtvigsplan) (Hæstrup 1990).

As Hannah Arendt aptly remarks of wartime Denmark: "It is the only case we know of where the Nazis met with open native resistance, from the very beginning." The preparatory efforts to set in place the bureaucracy of murder simply were not possible in Denmark. It is for this reason that the story of King Christian X wearing the Star of David himself is apocryphal: it never happened because the bureaucracy of murder never got that far along in Denmark. Jewish businesses were never taken, the Nazis never dared to institute a "Jewish law" in Denmark, and when the orders finally came to round up the Danish Jews for deportation, not only were the Danes ready to act decisively, but at least a few Germans - and they were spread throughout all levels in the occupying force - seem to have been so influenced by Danish attitudes toward the Jews that they participated with one eye closed in the events of October 1943, thereby making it easier for a good number of individual rescue actions that succeeded.

Though we are now separated by many years in time from the events of the resistance and the rescue, their significance for our world today has not diminished a whit. More than ever they need to be remembered. I quote from words of a Nobel Laureate, a man honoured worldwide for his commitment to non-violent resistance and civil disobedience in the face of unjust laws: 
Modern man has brought this whole world to an awe-inspiring threshold of the future. He has reached new and astonishing peaks of scientific success. He has produced machines that think and instruments that peer into the unfathomable ranges of interstellar space. He has built gigantic bridges to span the seas and gargantuan buildings to kiss the skies. His airplanes and space ships have dwarfed distance, placed time in chains and carved highways through the stratosphere. This is a dazzling picture of modern man's scientific and technological progress.

Yet in spite of these spectacular strides in science and technology, and still unlimited ones to come, something basic is missing. There is a sort of poverty of the spirit which stands in glaring contrast to our scientific and technological abundance. The richer we have become materially, the poorer we have become morally and spiritually. We have learned to fly the air like birds and swim the sea like fish, but we have not learned the simple art of living together as brothers.

The speaker was Martin Luther King, and the citation is taken from his Nobel Lecture presented in Oslo on 11 December 1964. This, to me, is the real significance of the rescue of the Danish Jews: it is a moral lesson in the simple art of living together as brothers. It provides as well a lesson in moral courage, and shows the possibility that human beings have of cooperating together to successfully resist forms of evil that, if not opposed, will destroy, impoverish and pollute everything they hold dear. Mass roundup, public humiliations, loss of all property, separation from loved ones and family, and transport in cattle cars to mass execution was never to befall the overwhelming majority of the Danish Jews. In the words of the poet Sylvia Plath: ${ }^{19}$

$[\ldots]$ my skin

Bright as a Nazi lampshade,

My right foot

A paperweight,

My face a featureless, fine

Jew linen.

Peel off the napkin

O my enemy.

Do I terrify?

This was the fate of millions of Jews all over Europe, but not of the overwhelming majority of the Danish Jews. In doing what they did, the Danes not only saved 7220 Jews, but they saved the honour of humanity, and for that we owe them a debt that can never be repaid.

${ }^{19}$ From Lady Lazarus, posthumously published in the anthology Ariel (1965). 
And what of Hal Koch, whose principled leadership in the cause of life has been the main topic of this paper? When martial law was declared on 29 August 1943, Koch was arrested and was one of the last to be let go. At the war's end he was marked for assassination, and only survived by jumping out of his second-storey balcony at the Nordisk Kollegium in Copenhagen. Badly injured, he succeeded in making his way to a fire station, and from there an ambulance brought him to Bispebjerg Hospital, where he was given a pseudonym and placed in a locked ward to ensure his survival. After the war he was to become the first principal of Krogerup Folk High School, a position he held from 1946 to $1956 .{ }^{20} \mathrm{He}$ continued his distinguished academic career, producing many additional works of lasting interest and significance. He became involved in a lively debate about the inner meaning and nature of democracy (Koch 1945). He founded and was the first director of an Institute for the study of Church History. But perhaps the most appropriate description of Hal Koch as a person comes from his old comrade Vilhelm Nielsen:

For a number of years I came to be relatively close to him. He could tolerate being seen at close quarters. Not all of those who have greatness in them can. Time after time he overwhelmed us with his human greatness, both in the completely ordinary and daily course of events and in the dramatic and fateful decisions of which these years had more than their share (Koch, Lindhardt and Skovmand 1969, 70-71).

Grundtvig, Ove Korsgaard tells us, distinguished between two forms of fighting or combat: a life-giving one and a destructive one. ${ }^{21}$ In his poetry he expressed in the following way the difference between the two forms of fighting:

Then we must learn the difference

Between sunshine and lightning

Though they both may burn

And both create a vision;

For common sense tells us

One light brings life.

The other strikes to kill! ${ }^{22}$

${ }^{20}$ Treated in Povl Nyboe Andersen, Hal Koch og Krogerup Højskole. Odense Universitetsforlag, 1993. See also Koch 1946.

21 Ove Korsgaard, personal communication. On this point, see further Korsgaard 1986. See also Korsgaard 1997, 2004.

${ }^{22}$ From Grundtvig's song "Nu skal det åbenbares" - see note 7 above. 
I close this paper ${ }^{23}$ with these words Vilhelm Nielsen wrote in remembrance of Hal Koch:

The word was his solution. In his thought and in his mouth it was in no sense a white flag, but resembled much more a sword. He swung it mercilessly, with a peculiar mixture of joy and humility [...] The emptiness after him is still felt.

\section{Bibliography}

Andersen, P. N. (1993), Hal Koch og Krogerup Højskole, Odense.

Andersen, R. (1976), Danmark i 30'erne. En historisk mosaik, Copenhagen.

Bessel, R. (ed.) (1987), Life in the Third Reich, New York.

Borish, S. (1991), The Land of the Living: The Danish Folk High Schools and Denmark's Non-violent Path to Modernization, Nevada City, CA.

- (1996), Danish Social Movements in a Time of Global Destabilization, Vejle.

- (1998), 'N. F. S. Grundtvig as charismatic prophet: an analysis of his life and work in the light of revitalization movement theory', Scandinavian Journal of Educational Research, Vol. 42, No. 3, 237-256.

Bradley, S. A. J. (tr., ed.) (2008), N. F. S. Grundtvig, A Life Recalled: An Anthology of Biographical Source Texts, Aarhus.

Dahl, H. F., Hagtvet, B. and Hjeltnes, G. (1982), Den norske nasjonalsosialismen: Nasjonal Samling 1933-1945 i tekst og bilder, Oslo.

Fogelman, E. (1994), Conscience and Courage: Rescuers of Jews during the Holocaust, New York.

Goldberger, L. (ed.) (1987), The Rescue of the Danish Jews, New York.

Hæstrup, J. (1990), Vildnis og "grundtvigsplan": om finansieringen af modstandsbevagelsen, Odense.

- (1976), Secret Alliance: A Study of the Danish Resistance Movement 194045 (tr. Alison Borch-Johansen), Odense.

Højskolesangbogen, 2006: Højskolesangbogen, 18th edition, Copenhagen.

Jakobsen, F. (1986), I Danmarks Frihedsråd, Copenhagen.

Koch, H. (1943), Grundtvig, Copenhagen.

- (1945), Hvad er demokrati? Copenhagen.

- (1946), 'Ved Krogerup Højskoles indvielse', Højskolebladet, No. 49.

Koch, P., Lindhardt, P. G. and Skovmand, R. (eds) (1969), Hal Koch og hans virke, Copenhagen.

Korsgaard, O. (1982), Kampen om kroppen. Dansk idrcets historie gennem $200 \stackrel{\circ}{a}$, Copenhagen.

- (1986), Kredsgang. Grundtvig som bokser, Copenhagen.

- (1997), Kampen om lyset. Dansk voksenoplysning gennem 500 år, Copenhagen.

${ }^{23}$ The author wishes to express his gratitude to the Thanks to Scandinavia Foundation for its funding, which supported the research for an earlier version of this paper. 
- (2004), Kampen om folket. Et dannelsesperspektiv på dansk historie gennem 500 år, Copenhagen.

Knudsen, J. (ed.) (1976), N. F. S. Grundtvig: Selected Writings, Philadelphia.

Kaarsted, T. (1991), Gyldendal og Politikens Danmarkshistorie, Vol. 13: Krise og Krig 1925-1950, Copenhagen.

Mills, C. Wright $(1959,2000)$, The Sociological Imagination, Oxford.

Nissen, H. (ed.) (1992), Kare Hal - Kare Koste. Breve 1940-42 mellem K. E. Løgstrup og Hal Koch, Copenhagen.

- and Poulsen, H. (1963), På dansk friheds grund: Dansk ungdomssamvirke og de celdres råd, Copenhagen.

Oliner, S. P., and Oliner, P. (1988), The Altruistic Personality: Rescuers of Jews in Nazi Europe, New York.

Plath, S. (1999), Ariel: The Restored Edition, New York.

Poulsen, H. (1995), 'Dansk modstand og tysk politik', Den jyske Historiker 71.

Prieme, H. (1982), En europaisk tragedie: beretningen om nazisternes folkemord på jøderne $i$ Tyskland, Polen, Frankrig og Danmark, Copenhagen.

Segal, G. (1982), Et folk på flugt - de danske jøder under Anden Verdenskrig, Copenhagen.

Skovgaard-Petersen, V. (1976), Dannelse og demokrati, Copenhagen.

Skovmand, R. (1951), De folkelige bevagelser i Danmark, Copenhagen.

Thaning, K. (1972), N. F. S. Grundtvig, Copenhagen.

US, bd. 8: Vol 8 in Holger Begtrup (ed.) (1904-09), Nik. Fred. Sev. Grundtvigs Udvalgte Skrifter, bind 1-10, Copenhagen.

Wivel, O. (1983), 'Med Grundtvig i ryggen' in Nissen, H. S. (1983), Efter Grundtvig: hans betydning i dag: essays, Copenhagen.

Yahil, L. (1969), The Rescue of Danish Jewry: Test of a Democracy, Philadelphia.

Note: where not otherwise specified, translations in this article are the author's. 